\title{
PENINGKATAN KINERJA OPERASI DAN PEMELIHARAAN JARINGAN IRIGASI PACAL KABUPATEN BOJONEGORO, JAWA TIMUR
}

\author{
Cynthia Rahma Dewi ${ }^{1}$, Eko Andi Suryo ${ }^{2}$, As'ad Munawir $^{2}$ \\ ${ }^{1}$ Mahasiswa / Program Magister / Jurusan Teknik Sipil / Fakultas Teknik / \\ Universitas Brawijaya \\ ${ }^{2}$ Dosen / Jurusan Teknik Sipil / Fakultas Teknik / Universitas Brawijaya \\ Jalan Mayjend Haryono 167 Malang 65145 Indonesia \\ Korespondensi : cynthiarahma0992@gmail.com
}

\begin{abstract}
Pacal Irrigation is an infrastructure that services most agricultural areas in Bojonegoro City, East Java. Some problems has been found in this facillities such as misdistribution of water, inadequate condition of facilities, illegal oulet canals, and non conformity in operation and maintenance (OM)procedures. This study aims to determine existing condition, main affecting factors and improving strategy of operational and maintenance at the Pacal Irrigation. Primary data was used in this study gathered from questionnaires of 93 respondents and 8 experts in Irrigation Management Study Area. Descriptive analysis was used to explain the existing condition of OM performance of Pacal Irrigation. Important Performance Analysis (IPA) method was applied to determine the main priority factors affecting OM Performance. Furthermore, the SWOT method then was used to define strategies for improving OM performance of PACAL Irrigation. The results of the IPA analysis show there are 11 main prioroty factors affecting OM performance of PACAL Irrigation network. Furthermore, from SWOT Analysis it can be suggesteded that the "growth" strategy can be applied at Pacal Irrigation.
\end{abstract}

Keywords: Pacal irrigation, operation and maintenance (OM), strategy

\section{PENDAHULUAN}

Pertumbuhan penduduk di Indonesia berkembang sangat pesat dan kebutuhan akan bahan pangan pokok terus meningkat akan tetapi jumlah lahan pertanian yang tersedia sangat terbatas. Mekipun Indonesia disebut sebagai negara agraris, Indonesia belum dapat memenuhi swasembada beras karena Indonesia sendiri masih mengimpor beras dari negara lain. Untuk mewujudkan kembali Indonesia sebagai swasembada beras [7] dalam jangka pendek pilihan yang layak untuk meningkatkan produktivitas usaha tani adalah melalui intensifikasi dengan meningkatkan optimalisasi pemanfaatan sumberdaya.

Usaha intensifikasi pertanian dapat dilakukan dengan cara pengelolaan jaringan irigasi yang baik seperti mengikuti pola dan tata tanam yang sesuai, pemenuhan dan pembagian kebutuhan air irigasi secara merata, sarana penunjang operasi dan pemeliharaan jaringan irigasi yang lengkap, serta perbaikan infrastruktur jaringan irigasi yang telah ada secara optimal. Pengelolaan jaringan irigasi yang baik akan menunjang peningkatan produksi pertanian khususnya padi dalam memenuhi program swasembada beras, meningkatkan kesejahteraan dan pendapatan petani, serta mengoptimalkan pemanfaatan sumber daya air.

Kabupaten Bojonegoro merupakan kabupaten yang mayoritas penduduknya berusaha pada sektor pertanian. Untuk menunjang perkembangan sektor pertanian di wilayah Kabupaten Bojonegoro khususnya Daerah Irigasi Pacal, diperlukan perencanaan, pengembangan serta pengelolaan irigasi yang berkelanjutan. Menurut hasil wawancara dengan petugas UPT, kondisi eksisting Waduk Pacal mengalami sedimentasi yang sangat dalam sehingga luas tampungan waduk menjadi berkurang. Selain itu, kondisi saluran dan bangunan Jaringan Irigasi Pacal, beberapa mengalami kerusakan seperti rusaknya spillway 
pada bangunan utama. Hal tersebut mengakibatkan kinerja operasional dan pemeliharaan Jaringan Irigasi Pacal menurun. Oleh karena itu, penelitian ini penting dilakukan untuk mengevaluasi dan menemukan strategi untuk meningkatkan kinerja operasi dan pemeliharaan Jaringan Irigasi Pacal sehingga dapat lebih optimal. Selain itu, prasarana dan sarana irigasi dapat berfungsi lebih efektif dan efisien sehingga dapat meningkatkan intensitas tanam sesuai dengan harapan dan dapat meningkatkan pendapatan petani.

Berdasarkan latar belakang yang dibahas, penulis dapat merumuskan permasalahanpermasalan sebagai berikut:

1. Bagaimana analisis kondisi eksisting Jaringan Irigasi Pacal dari segi prasarana fisik, realisasi dan intensitas tanam, serta kemampuan untuk memenuhi kebutuhan air irigasi?

2. Apa saja faktor-faktor yang menjadi prioritas dalam penanganan kinerja operasi dan pemeliharaan Jaringan Irigasi Pacal berdasarkan persepsi dan kepentingan dari anggota HIPPA?

3. Bagaimana upaya-upaya/strategi untuk mengningkatkan kinerja operasi Jaringan Irigasi Pacal?

Tujuan dilakukannya penelitian ini adalah sebagai berikut :

1. Untuk mengetahui kondisi eksisting Jaringan Irigasi Pacal dari segi prasarana fisik, realisasi dan intensitas tanam, serta kemampuan untuk memenuhi kebutuhan air irigasi

2. Untuk mengetahui faktor-faktor yang menjadi prioritas penanganan dalam penanganan kinerja operasi dan pemeliharaan Jaringan Irigasi Pacal.

3. Untuk mengetahui bagaimana cara meningkatkan kinerja operasi dan pemeliharaan Jaringan Irigasi Pacal.

Batasan masalah dari penelitian ini adalah

1. Daerah Irigasi yang menjadi tempat penelitian adalah Daerah Irigasi Pacal seluas Ha yang 16.688 Ha terdiri dari Daerah Irigasi Pacal Kiri seluas $1.965 \mathrm{Ha}$ dan Daerah Irigasi Pacal Kanan seluas $14.723 \mathrm{Ha}$ yang secara administratif terletak di Kabupaten Bojonegoro.

2. Obyek penelitian ini adalah Jaringan Irigasi Pacal di Kabupaten Bojonegoro, Jawa Timur.
3. Responden yang disurvei untuk Analisis IPA adalah para petani pengguna air irigasi (HIPPA), serta untuk Analisis SWOT adalah para pejabat/ahli yang berwenang dalam menangani pengelolaan air irigasi pada Jaringan Irigasi Pacal

4. Penelitian ini dilakukan berdasarkan tingkat persepsi petani pengguna air irigasi terhadap kinerja operasi dan pemeliharaan Jaringan Irigasi Pacal. Penelitian ini mengkaji kinerja operasi dan pemeliharaan berdasarkan indikator yang diambil dari Peraturan Menteri Pekerjaan Umum No. 32 tahun 2007 tentang operasi dan pemeliharaan jaringan irigasi yang didalamnya terdapat atribut-atribut kinerja operasi dan pemeliharaan yang akan dinilai. Indikator-indikator tersebut masuk dalam variabel kondisi prasarana fisik, produktivitas tanam, pemeliharaan saluran irigasi, sarana penunjang, organisasi personalia, dokumentasi dan Himpunan Petani Pemakai Air (HIPPA).

5. Metode yang digunakan untuk mengetahui kepuasan dan kepentingan berdasarkan persepsi petani wilayah Daerah Irigasi Pacal adalah metode Importance Performance Analysis (IPA), Metode yang digunakan dalam merumuskan strategi peningkatan kinerja operasi dan pemeliharaan jaringan irigasi adalah Metode SWOT EFAS IFAS.

\section{TINJAUAN PUSTAKA}

Jaringan irigasi adalah saluran, bangunan, dan bangunan pelengkap yang merupakan satu kesatuan yang diperlukan untuk penyediaan, pembagian, pemberian, penggunaan, dan pembuangan air irigasi. Secara hirarki, jaringan irigasi dibagi menjadi dua yaitu : jaringan utama dan jaringan tersier. Jaringan utama meliputi jaringan primer dan jaringan sekunder. Jaringan irigasi primer adalah bagian dari jaringan irigasi yang terdiri atas bangunan utama, saluran induk/primer, saluran pembuangannya, bangunan bagi, bangunan bagi-sadap, bangunan sadap, dan bangunan pelengkapnya. Jaringan irigasi sekunder adalah bagian dari jaringan irigasi yang terdiri atas saluran sekunder, saluran pembuangannya, bangunan bagi, bangunan bagi-sadap, bangunan sadap, dan bangunan pelengkapnya.

Sedangkan jaringan irigasi tersier adalah jaringan irigasi yang berfungsi sebagai 
prasarana pelayanan air irigasi dalam petak tersier yang terdiri atas saluran tersier, saluran kuarter dan saluran pembuang, boks tersier, boks kuarter, serta bangunan pelengkapnya. Suatu kesatuan wilayah yang mendapatkan air dari suatu jarigan irigasi disebut dengan Daerah Irigasi [1].

Kinerja jaringan irigasi adalah fungsi dari sejumlah variabel teknik, fisik, sosial dan ekonomi. Suatu variabel indikator tidak dapat digunakan untuk mengukur semua aspek kinerja ataupun tindakan yang diperlukan untuk meningkatkan kinerja. Indikator kinerja diperhitungkan berdasarkan aspek organisasian HIPPA, infrastruktur jaringan dengan sub indikator saluran pembawa, bangunan bagi/sadap dan jalan usaha tani, dan pengaturan air dengan sub indikator pendistribuan air, pengawasan penggunaan air dan pemeliharaan jaringan [1].

Kinerja jaringan irigasi tercermin dari kemampuannya untuk mendukung ketersediaan air irigasi pada areal layanan irigasi (command area) yang kondusif untuk penerapan pola tanam yang direncanakan [2]. Kinerja jaringan irigasi yang buruk mengakibatkan luas areal sawah yang irigasinya baik menjadi berkurang. Secara umum, kinerja jaringan irigasi yang buruk mengakibatkan meningkatnya water stress yang dialami tanaman (baik akibat kekurangan ataupun kelebihan air) sehingga pertumbuhan vegetatif dan generatif tanaman tidak optimal. Kerugian yang timbul akibat water stress tidak hanya berupa produktivitas tanaman sangat menurun, tetapi mencakup pula mubazirnya sebagian masukan usaha tani yang telah diaplikasikan (pupuk, tenaga kerja, dan lain-lain).

\section{KERANGKA PENELITIAN 3.1. Konsep Penelitian}

Untuk kerangka penelitian dalam penelitian ini dijelaskan pada Gambar 1.

\subsection{Definisi Operasional Variabel}

Definisi operasional variabel adalah pengertian variabel yang diungkap dalam definisi konsep tersebut, secara operasional, secara praktik, dan secara nyata dalam lingkup obyek penelitian [5]. Variabel dalam penelitian ini diambil di Peraturan Menteri Pekerjaan Umum Nomor 32/PRT/M/2007 tentang Operasi dan Pemeliharaan Jaringan Irigasi, Lampiran I Indeks Kinerja Sistem Irigasi [3].

Tabel 1. Definisi operasional variabel

\begin{tabular}{|c|c|c|c|c|}
\hline No & Variabel & Definisi & Indikator & Kode \\
\hline \multirow[t]{8}{*}{1.} & $\begin{array}{l}\text { Kondisi } \\
\text { Prasarana }\end{array}$ & $\begin{array}{l}\text { Variabel untuk } \\
\text { mengetahui }\end{array}$ & $\begin{array}{l}\text { Kondisi bangunan } \\
\text { utama }\end{array}$ & $\mathrm{X} 1.1$ \\
\hline & Fisik (X1) & $\begin{array}{l}\text { bagaimana } \\
\text { kondisi prasarana }\end{array}$ & $\begin{array}{l}\text { Kondisi saluran } \\
\text { pembawa }\end{array}$ & $\mathrm{X} 1.2$ \\
\hline & & $\begin{array}{l}\text { fisik suatu daerah } \\
\text { irigasi }\end{array}$ & $\begin{array}{l}\text { Kondisi bangunan } \\
\text { pengatur }\end{array}$ & $\mathrm{X} 1.3$ \\
\hline & & & $\begin{array}{l}\text { Kondisi bangunan } \\
\text { pelengkap }\end{array}$ & $\mathrm{X} 1.4$ \\
\hline & & & $\begin{array}{lr}\text { Kondisi saluran } \\
\text { pembuang dan } \\
\text { bangunannya }\end{array}$ & $\mathrm{X} 1.5$ \\
\hline & & & $\begin{array}{l}\text { Kondisi jalan } \\
\text { masuk }\end{array}$ & $\mathrm{X} 1.6$ \\
\hline & & & $\begin{array}{l}\text { Kondisi jalan } \\
\text { inspeksi }\end{array}$ & $\mathrm{X} 1.7$ \\
\hline & & & $\begin{array}{l}\text { Kondisi } \\
\text { perumahan }\end{array}$ & $\mathrm{X} 1.8$ \\
\hline \multirow[t]{3}{*}{2.} & $\begin{array}{l}\text { Produktivi- } \\
\text { tas }\end{array}$ & $\begin{array}{l}\text { Variabel untuk } \\
\text { mengetahui }\end{array}$ & $\begin{array}{l}\text { Pemenuhan } \\
\text { kebutuhan air }\end{array}$ & $\mathrm{X} 2.1$ \\
\hline & Tanam (X2) & $\begin{array}{l}\text { bagaimana } \\
\text { produktivitas }\end{array}$ & $\begin{array}{l}\text { Realisasi luas } \\
\text { tanam }\end{array}$ & $\mathrm{X} 2.2$ \\
\hline & & $\begin{array}{l}\text { tanam suatu } \\
\text { daerah irigasi. }\end{array}$ & Produktivitas padi & $\mathrm{X} 2.3$ \\
\hline \multirow[t]{3}{*}{3.} & $\begin{array}{l}\text { Sarana } \\
\text { Penunjang } \\
\text { (X3) }\end{array}$ & $\begin{array}{l}\text { Variabel untuk } \\
\text { mengetahui } \\
\text { bagaimana }\end{array}$ & $\begin{array}{l}\text { Kelengkapan } \\
\text { peralatan Operasi } \\
\text { dan Pemeliharaan }\end{array}$ & $\mathrm{X} 3.1$ \\
\hline & & kelengkapan & Alat-alat kantor & $\mathrm{X} 3.2$ \\
\hline & & $\begin{array}{l}\text { sarana penunjang } \\
\text { yang digunakan } \\
\text { dalam } \\
\text { pengelolaan } \\
\text { jaringan irigasi }\end{array}$ & Alat komunikasi & $\mathrm{X} 3.3$ \\
\hline \multirow[t]{3}{*}{4.} & $\begin{array}{l}\text { Organisasi } \\
\text { Personalia } \\
\text { (X4) }\end{array}$ & $\begin{array}{l}\text { Variabel yang } \\
\text { menggambarkan } \\
\text { bagaimana } \\
\text { kondisi personalia }\end{array}$ & $\begin{array}{l}\text { Pengaturan dan } \\
\text { penyusunan } \\
\text { organisasi Operasi } \\
\text { dan Pemeliharaan }\end{array}$ & $\mathrm{X} 4.1$ \\
\hline & & $\begin{array}{l}\text { di dalam } \\
\text { organisasi } \\
\text { pengelolaan } \\
\text { jaringan irigasi. }\end{array}$ & $\begin{array}{l}\text { Rasio jumlah } \\
\text { personel dengan } \\
\text { kebutuhan } \\
\text { sesungguhnya }\end{array}$ & $\mathrm{X} 4.2$ \\
\hline & & & $\begin{array}{l}\text { Pemahaman } \\
\text { personalia } \\
\text { mengenai OP }\end{array}$ & $\mathrm{X} 4.3$ \\
\hline \multirow[t]{3}{*}{5.} & $\begin{array}{l}\text { Dokumentasi } \\
\text { (X5) }\end{array}$ & $\begin{array}{l}\text { Variabel untuk } \\
\text { mengetahui }\end{array}$ & $\begin{array}{l}\text { Kelengkapan buku } \\
\text { data Daerah Irigasi }\end{array}$ & $\mathrm{X} 5.1$ \\
\hline & & $\begin{array}{l}\text { bagaimana } \\
\text { kelengkapan data- }\end{array}$ & $\begin{array}{l}\text { Kelengkapan peta } \\
\text { dan gambar }\end{array}$ & $\mathrm{X} 5.2$ \\
\hline & & $\begin{array}{l}\text { data pada layanan } \\
\text { irigasi. }\end{array}$ & Pedoman OP & $\mathrm{X} 5.3$ \\
\hline \multirow[t]{9}{*}{6.} & $\begin{array}{l}\text { Himpunan } \\
\text { Petani }\end{array}$ & $\begin{array}{l}\text { Variabel untuk } \\
\text { mengetahui }\end{array}$ & $\begin{array}{l}\text { GHIPPA/HIPPA } \\
\text { berbadan hukum }\end{array}$ & X6.1 \\
\hline & Pemakai Air & partisipasi & Kondisi & X6.2 \\
\hline & (HIPPA) (X6) & $\begin{array}{l}\text { anggota HIPPA } \\
\text { dalam }\end{array}$ & $\begin{array}{l}\text { kelembagaan } \\
\text { HIPPA }\end{array}$ & \\
\hline & & $\begin{array}{l}\text { pengelolaan } \\
\text { jaringan irigasi. }\end{array}$ & 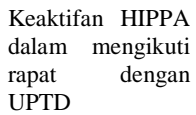 & X6.3 \\
\hline & & & $\begin{array}{l}\text { Partisipasi HIPPA } \\
\text { dalam penanganan } \\
\text { bencana alam }\end{array}$ & X6.4 \\
\hline & & & $\begin{array}{l}\text { Pertisipasi HIPPA } \\
\text { dalam } \\
\text { penulusuran } \\
\text { Jaringan Irigasi }\end{array}$ & X6.5 \\
\hline & & & 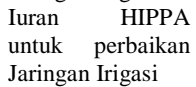 & X6.6 \\
\hline & & & $\begin{array}{l}\text { Partisipasi HIPPA } \\
\text { dalam }\end{array}$ & X6.7 \\
\hline & & & $\begin{array}{l}\text { perencanaan tata } \\
\text { tanam }\end{array}$ & \\
\hline
\end{tabular}

Sumber : Hasil Analisa 


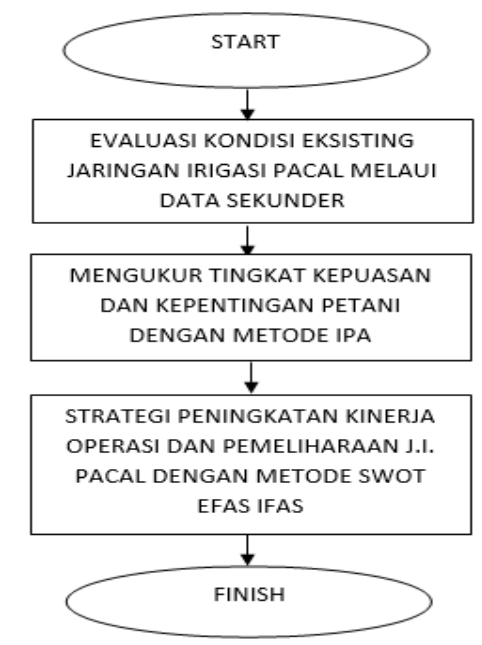

Gambar 1. Diagram alir kerangka pemikiran

\subsection{Hipotesis Penelitian}

Berdasarkan tujuan penelitian maka hipotesis penelitian ini sebagai berikut:

Terdapat 6 aspek yang berpengaruh terhadap peningkatan kinerja operasi dan pemeliharaan Jaringan Irigasi Pacal, yaitu :

1. Kondisi prasarana fisik

2. Produktivitas tanam

3. Sarana penunjang

4. Organisasi personalia

5. Dokumentasi

6. Himpunan Petani Pemakai Air (HIPPA)

\section{METODE PENELITIAN}

\subsection{Tahapan Penelitian}

Tahapan penilitian merupakan suatu proses memperoleh atau mendapatkan suatu pengetahuan atau memecahkan permasalahan yang dilakukan secara ilmiah, sistematis dan logis [6]. Tahapan Tahapan Penelitian ini diawali dengan Rumusan Masalah dan Tujuan Penelitian. Tahapan Penelitian dapat dilihat pada Gambar 2 berikut ini:

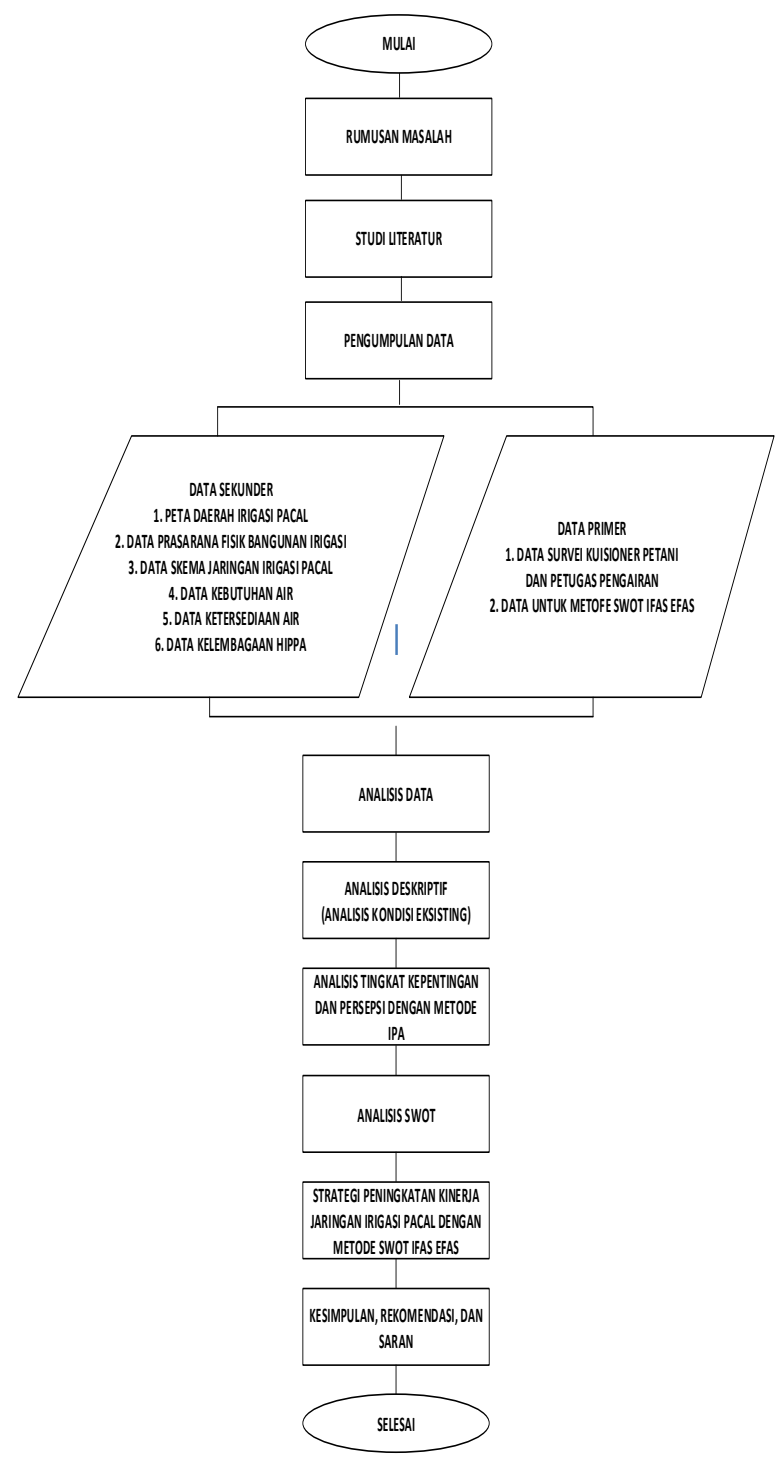

Gambar 2. Bagan alur penelitian

\subsection{Populasi dan Sampel Penelitian}

Jenis populasi dalam penelitian ini adalah populasi terbatas yaitu jumlah para petani yang termasuk dalam Himpunan Petani Pemakai Air (HIPPA) pada Daerah Irigasi Pacal telah diketahui.

Metode penentuan sampel yang digunakan dalam penelitian ini adalah random sampling. Jika jumlah populasi telah diketahui, maka menggunakan rumus Slovin [5] : 


$$
\begin{array}{cl}
\multicolumn{1}{c}{n=} & \frac{N}{N \cdot d^{2}+1} \\
\operatorname{dimana} & : \\
n & =\text { Jumlah sampel } \\
d & \quad=\text { Presisi yang ditetapkan } \\
N & \quad=\text { Jumlah populasi }
\end{array}
$$

\subsection{Pengujian Instrumen}

Uji Validitas dilakukan dengan menghitung corrected item-total correlation coefficient. Rumus corrected item-total correlation coefficient adalah sebagai berikut [5] :

$r_{x(y-x)}=\frac{\left(r_{(x y)} s_{y}-s_{x}\right)}{\sqrt{s_{y}^{2}+s_{x}^{2}+2 r_{x y} s_{x} s_{y}}}$

dimana :

$r_{x y}=\frac{\sum_{i=1}^{n} x i y i-\frac{\sum_{i=1}^{n} x_{i} \sum_{i=1}^{n} y_{i}}{n}}{\sqrt{\left(\sum_{i=1}^{n} x_{i}-\frac{\left(\sum_{i=1}^{n} x_{i}\right)^{2}}{n}\right)\left(\sum_{i=1}^{n} y_{i}-\frac{\left(\sum_{i=1}^{n} y_{i}\right)^{2}}{n}\right)}}$

dimana :

$\mathrm{n} \quad=$ ukuran sampel

$\mathrm{x} \quad=$ skor indikator

$\mathrm{y} \quad=$ total skor seluruh indikator

$r_{x y}=$ koefisien korelasi skor butir-total sebelum dikoreksi

$s x=$ simpangan baku skor butir yang bersangkutan

sy = simpangan baku total skor seluruh indikator

Apabila $r_{x(y-x)}>r_{\text {tabel }}$ maka alat ukur telah valid

Uji reliabilitas dilakukan dengan menggunakan alpha cronbach. Perhitungan alpha cronbach dapat dilakukan dengan rumus berikut :

$\alpha=\frac{k}{k-1}\left(1-\frac{\sum_{i=1}^{k} \sigma_{x_{i}}^{2}}{\sigma_{y}^{2}}\right)$

dimana :

$\mathrm{k}$ = banyaknya indikator dalam sebuah perubah

$\sigma_{x_{i}}^{2}=$ ragam indikator ke-i

$\sigma_{y}^{2}=$ ragam total skor

Apabila $\alpha>0,6$ maka alat ukur telah reliabel

\subsection{Teknik Analisis Data}

Teknik analisis yang digunakan dalam penelitian ini antara lain:

1. Analisis Deskriptif
Analisis ini digunakan untuk menggambarkan data yang telah terkumpul berdasarkan jawaban responden melalui distribusi item dari masing-masing variabel. Penyajian data yang telah terkumpul pembahasannya dilakukan dengan menggunakan tabel frekuensi.

2. Analisis IPA (Importance Performance Analysis)

Dalam menganalisis data penelitian ini, digunakan metode deskriptif kualitatifkuantitatif untuk menjawab perumusan masalah mengenai sampai sejauh mana tingkat kinerja Jaringan Irigasi Pacal dari persepsi Himpunan Petani Pemakai Air (HIPPA) dengan menggunakan Metode Importance Peformance Analysis (IPA). Tahapan-tahapan Analisa IPA dalam penelitian ini adalah sebagai berikut :

a. Penentuan Variabel

Variabel-variabel yang dipakai dalam analisa kinerja Jaringan Irigasi Pirang dengan Metode IPA adalah sebagai berikut :

- Kondisi prasarana fisik

- Produktivitas tanam

- Sarana Penunjang OP

- Organisasi Personalia

- Dokumentasi

- Himpunan Petani Pemakai Air (HIPPA)

b. Pembagian Kuisioner

Daftar pertanyaan yang diajukan dalam kuisioner berdasarkan variabel-variabel diatas dengan menggunakan skala prioritas terhadap tingkat kepentingan dan tingkat kepuasan/kinerja menurut Himpunan Petani Pemakai Air (HIPPA).

3. Analisis SWOT (Strengths, Weaknesses, Oppurtunities, Threats)

Analisis SWOT IFAS EFAS bertujuan untuk mengidentifikasi berbagai faktor secara sistematis untuk merumuskan suatu strategi pembangunan daerah [4]. Sebagai sebuah konsep dalam manajemen strategik, teknik ini menekankan mengenai perlunya penilaian lingkungan eksternal dan internal, serta kecenderungan perkembangan/perubahan di masa depan sebelum menetapkan sebuah strategi. Analisis ini didasarkan pada logika yang dapat memaksimalkan kekuatan (Strenghts) dan peluang (Opportunities), namun secara bersamaan dapat meminimalkan kelemahan (Weaknesses) dan ancaman (Threats). 


\section{HASIL DAN PEMBAHASAN}

\subsection{Analisa Kondisi Eksisting Jaringan Irigasi Pacal}

Analisa Kondisi Eksisting bertujuan untuk mengetahui kondisi eksisting pada Jaringan Irigasi Pacal yang meliputi : Prasarana Fisik Jaringan Irigasi Pacal, Realisasi dan Intensitas Tanam, Pemenuhan Kebutuhan Irigasi, dan Profil Responden HIPPA.

Realisasi tanam padi pada Musim Hujan (MH) sebesar 15,096 Ha. Realisasi tanam padi mengalami penurunan pada Musim Kemarau I (MK I) menjadi 14,582 Ha dan pada Musim Kemarau II (MK II) menjadi 9,091 Ha. Untuk intensitas tanam pada Daerah Irigasi Pacal mencapai 90,46\% pada Musim Hujan (MH), $87,75 \%$ pada Musim Kemarau I (MK I), dan 90,59\% pada Musim Kemarau II (MK II)

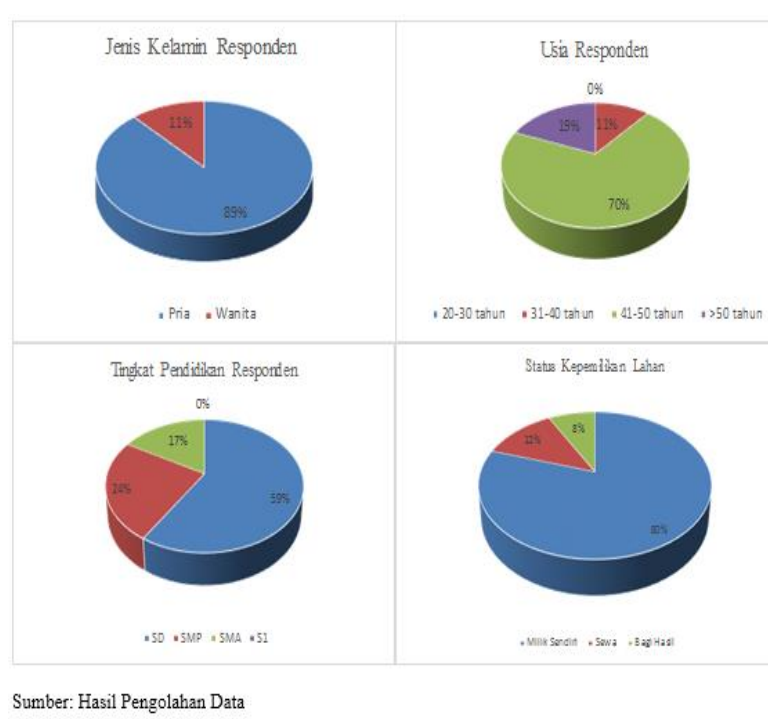

Gambar 3. Profil responden

Dari Gambar 3 terlihat, berdasarkan kategori gender, $89 \%$ responden HIPPA di Daerah Irigasi Pacal memiliki gender pria. Berdasarkan kategori usia, $70 \%$ responden berusia antara 40-50 tahun. Hal ini menunjukkan bahwa anggota HIPPA masih tergolong usia produktif. Namun, minat pemuda yang berusaha pada bidang pertanian masih rendah. Dengan adanya perkembangan pendidikan, beberapa pemuda di daerah ini dapat menempuh pendidikan yang lebih tinggi sehingga cenderung ingin mencari pekerjaan selain menjadi petani.
Berdasarkan kategori tingkat pendidikan, 59\% tingkat pendidikan responden HIPPA relatif rendah karena hanya menempuh pendidikan SD. Hal ini cukup menghambat dalam perkembangan kinerja HIPPA karena lebih sulit untuk menciptakan inovasi atau perubahan-perubahan pada bidang OP. Dalam kegiatan Operasi dan Pemeliharaan Jaringan Irigasi, kurang mampu untuk menganalisa, merumuskan masalah yang terjadi di lapangan, dan melakukan kegiatan secara berkelompok yang berkaitan dengan operasi dan pemeliharaan.

Berdasarkan status kepemilikan lahan, $80 \%$ responden HIPPA berstatus pemilik lahan. Hal tersebut menunjukkan bahwa bila lahan sawah dikelola dengan baik akan meningkatkan pendapatan para petani.

\subsection{Analisa Faktor-Faktor Yang Mempengaruhi Kinerja Operasi dan Pemeliharaan Jaringan Irigasi Pacal}

Dalam menentukan faktor-faktor yang mempengaruhi kinerja operasi dan pemeliharaan Jaringan Irigasi Pacal bagian hulu-hilir menggunakan metode Analisis IPA (Importance Performance Analysis). Variabel dan indikator dapat dilihat pada Tabel 1.

Adapun tahap-tahap analisisnya sebagai berikut :

1) Uji Validitas

Berdasarkan Tabel 2 dapat dilihat bahwa seluruh item instrumen penelitian memenuhi persyaratan uji validitas dan dinyatakan valid karena diketahu nilai Rtabel $=0,207$ sehingga dapat diketahui bahwa nilai $r_{\text {hitung }}$ lebih besar dari $r_{\text {tabel }}$ untuk semua item atribut pelayanan.

2) Uji Realibilitas

Berdasarkan Tabel 3, semua item instrumen penelitian dapat dikatakan Reliabel, karena telah memenuhi kriteria pengujian reliabilitas item instrumen yang digunakan, yaitu Alpha Cronbach lebih besar atau sama dengan 0,6

3) Penentuan Faktor-Faktor Prioritas Utama Peningkatan Kinerja Operasi dan Pemeliharaan Jaringan Irigasi Pacal 
Tabel 2. Uji validitas instrumen penelitian

\begin{tabular}{|c|c|c|c|c|c|}
\hline \multirow[t]{2}{*}{ Variabel } & \multirow[t]{2}{*}{ Item } & \multicolumn{3}{|c|}{ Uji Validitas } & \multirow[t]{2}{*}{ Ket. } \\
\hline & & $r_{\text {hitung }}$ & Sign.(p) & $r_{\text {tabel }}$ & \\
\hline Aspek & $\mathrm{X} 1.1$ & 0,439 & 0,000 & 0,207 & Valid \\
\hline Kondisi & $\mathrm{X} 1.2$ & 0,333 & 0,000 & 0,207 & Valid \\
\hline Prasarana & $\mathrm{X} 1.3$ & 0,326 & 0,000 & 0,207 & Valid \\
\hline \multirow[t]{8}{*}{ Fisik (X1) } & $\mathrm{X} 1.4$ & 0,408 & 0,000 & 0,207 & Valid \\
\hline & $\mathrm{X} 1.5$ & 0,402 & 0,000 & 0,207 & Valid \\
\hline & X1.6 & 0,515 & 0,000 & 0,207 & Valid \\
\hline & $\mathrm{X} 1.7$ & 0,441 & 0,000 & 0,207 & Valid \\
\hline & $\mathrm{X} 1.8$ & 0,439 & 0,000 & 0,207 & Valid \\
\hline & X1.9 & 0,506 & 0,000 & 0,207 & Valid \\
\hline & $\mathrm{X} 1.10$ & 0,492 & 0,000 & 0,207 & Valid \\
\hline & $\mathrm{X} 1.11$ & 0,545 & 0,000 & 0,207 & Valid \\
\hline Produktivi & $\mathrm{X} 2.1$ & 0,328 & 0,000 & 0,207 & Valid \\
\hline tas Tanam & X2.2 & 0,495 & 0,000 & 0,207 & Valid \\
\hline (X2) & $\mathrm{X} 2.3$ & 0,475 & 0,000 & 0,207 & Valid \\
\hline Sarana & X3.1 & 0,906 & 0,000 & 0,207 & Valid \\
\hline Penunjang & X3.2 & 0,852 & 0,000 & 0,207 & Valid \\
\hline OP $(\mathrm{X3})$ & X3.3 & 0,734 & 0,000 & 0,207 & Valid \\
\hline Organisasi & $\mathrm{X} 4.1$ & 0,81 & 0,000 & 0,207 & Valid \\
\hline \multirow{2}{*}{$\begin{array}{c}\text { Personalia } \\
\text { (X4) }\end{array}$} & $\mathrm{X} 4.2$ & 0,606 & 0,000 & 0,207 & Valid \\
\hline & $\mathrm{X} 4.3$ & 0,547 & 0,000 & 0,207 & Valid \\
\hline \multirow{3}{*}{$\begin{array}{l}\text { Dokument } \\
\text { asi (X5) }\end{array}$} & X5.1 & 0,95 & 0,000 & 0,207 & Valid \\
\hline & X5.2 & 0,953 & 0,000 & 0,207 & Valid \\
\hline & X5.3 & 0,953 & 0,000 & 0,207 & Valid \\
\hline Himpunan & X6.1 & 0,894 & 0,000 & 0,207 & Valid \\
\hline Petani & X6.2 & 0,625 & 0,000 & 0,207 & Valid \\
\hline Pemakani & X6.3 & 0,615 & 0,000 & 0,207 & Valid \\
\hline Air & X6.4 & 0,69 & 0,000 & 0,207 & Valid \\
\hline (HIPPA) & X6.5 & 0,735 & 0,000 & 0,207 & Valid \\
\hline (X6) & X6.6 & 0,677 & 0,000 & 0,207 & Valid \\
\hline
\end{tabular}

Tabel 3. Uji reliabilitas instrumen penelitian

\begin{tabular}{|c|c|c|}
\hline Variabel & $\begin{array}{c}\text { Alpha } \\
\text { Cronbach }\end{array}$ & Keterangan \\
\hline $\begin{array}{c}\text { Aspek Kondisi } \\
\text { Prasarana Fisik (X1) }\end{array}$ & 0,778 & $\begin{array}{c}\text { Tingkat kehandalan } \\
\text { tinggi }\end{array}$ \\
\hline $\begin{array}{c}\text { Produktivitas Tanam } \\
\text { (X2) }\end{array}$ & 0,618 & $\begin{array}{c}\text { Tingkat kehandalan } \\
\text { tinggi }\end{array}$ \\
\hline $\begin{array}{c}\text { Sarana Penunjang } \\
\text { OP (X3) }\end{array}$ & 0,911 & $\begin{array}{c}\text { Tingkat kehandalan } \\
\text { sangat tinggi }\end{array}$ \\
\hline $\begin{array}{c}\text { Organisasi } \\
\text { Personalia (X4) }\end{array}$ & 0,791 & $\begin{array}{c}\text { Tingkat kehandalan } \\
\text { tinggi }\end{array}$ \\
\hline Dokumentasi (X5) & 0,977 & $\begin{array}{c}\text { Tingkat kehandalan } \\
\text { sangat tinggi }\end{array}$ \\
\hline $\begin{array}{l}\text { Himpunan Petani } \\
\text { Pemakai Air } \\
\text { (HIPPA) }\end{array}$ & 0,882 & $\begin{array}{c}\text { Tingkat kehandalan } \\
\text { tinggi }\end{array}$ \\
\hline
\end{tabular}

Setelah dilakukan analisis tingkat kesesuaian kepuasan dan persepsi, dilakukan penentuan faktor-faktor prioritas utama peningkatan kinerja operasi dan pemeliharaan Jaringan Irigasi Pacal. Dari perhitungan skor tiap variabel dan perhitungan skor rata-rata tingkat kepentingan dan tingkat kepuasan/kinerja, kemudian diplotkan ke diagram kartesius seperti Gambar 4 - Gambar 6 sehingga didapatkan posisi kuadran tiap variabel.

Berikut adalah cara mengeplotkan hasil perhitungan ke dalam diagram kartesius : a. Kuadran I: menunjukkan faktor yang mempengaruhi anggota Himpunan Petani Pemakai Air (HIPPA) kurang penting, akan tetapi pelaksanaanya berlebihan. Dianggap kurang penting tetapi sangat memuaskan.

b. Kuadran II : menunjukkan beberapa faktor yang kurang penting pengaruhnya bagi para anggota Himpunan Petani Pemakai Air (HIPPA), pelaksanaannya oleh Pemerintah biasa-biasa saja. Dianggap kurang penting dan kurang memuaskan.

c. Kuadran III : menunjukkan unsur jasa pokok yang telah berhasil dilaksanakan Pemerintah, untuk itu wajib dipertahakannya. Dianggap sangat penting dan sangat memuaskan

d. Kuadran VI : menunjukkan faktor atau atribut yang dianggap mempengaruhi kepuasan para anggota Himpunan Petani Pemakai Air (HIPPA), termasuk unsurunsur jasa yang dianggap sangat penting, namun Pemerintah belum melaksanakannya sesuai keinginan para petani. Sehingga mengecewakan/tidak puas.

Dalam penelitian ini, analisis kuadran yang terletak pada kuadran IV menunjukkan faktor-faktor prioritas utama peningkatan kinerja operasi dan pemeliharaan Jaringan Irigasi Pacal

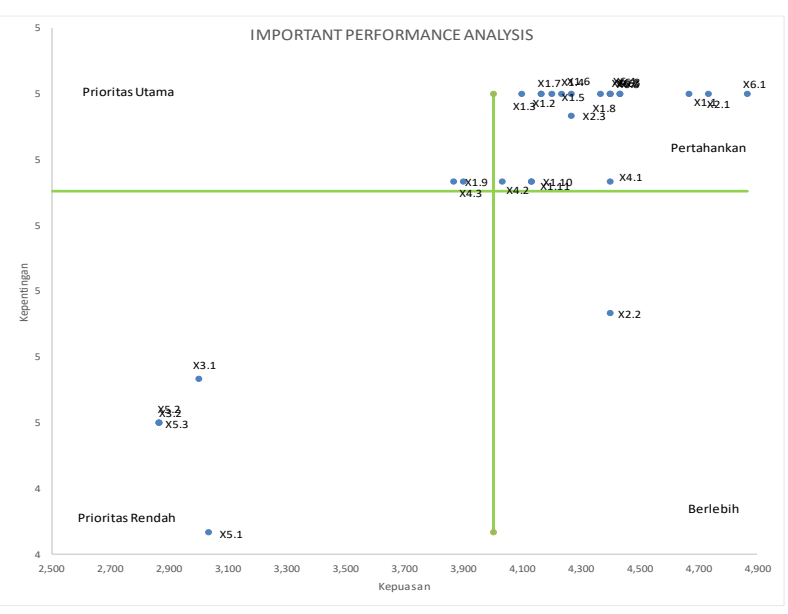

Gambar 4. Diagram kartesius tingkat kesesuaian kepuasan dan persepsi HIPPA bagian hulu 


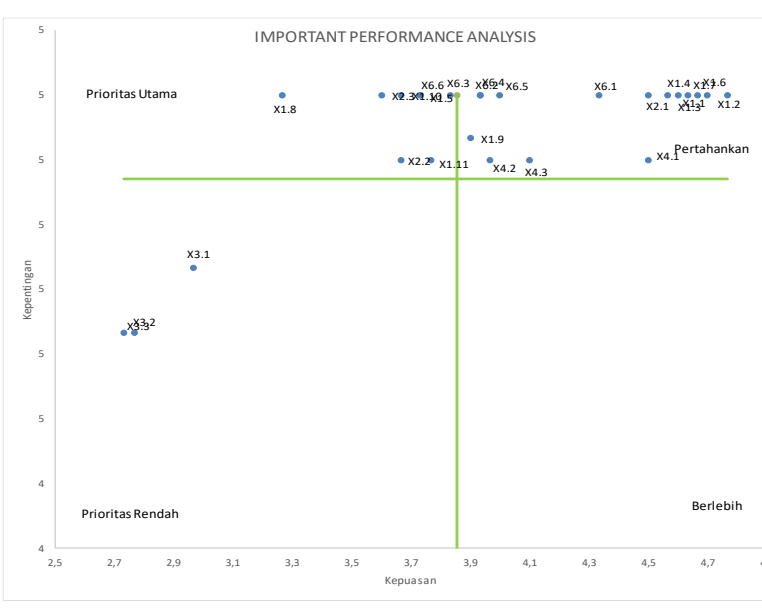

Gambar 5. Diagram kartesius tingkat kesesuaian kepuasan dan persepsi HIPPA bagian tengah

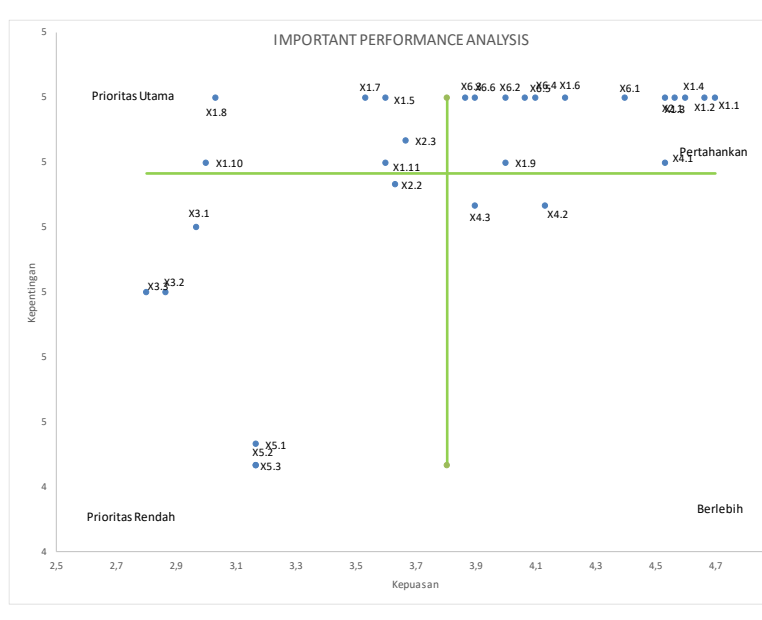

Gambar 6. Diagram kartesius tingkat kesesuaian kepuasan dan persepsi HIPPA bagian hilir

\subsection{Strategi Peningkatan Kinerja Operasi dan Pemeliharaan Jaringan Irigasi Pacal}

Langkah awal dari proses menyusun strategi peningkatan kinerja Operasi dan Pemeliharaan Jaringan Irigasi Pacal adalah menganalisis faktor-faktor strategis yang merupakan kesesuaian antara peluang-peluang eksternal dan kekuatan-kekuatan internal, disamping memperhatikan ancaman-ancaman eksternal dan kelemahan-kelemahan internal. Faktor-faktor tersebut diperoleh dari hasil Analisa IPA dan wawancara langsung kepada stakeholder. Berikut ini adalah hasil analisa tersebut yang dimasukkan dalam kategori S-WO-T:

\section{- $\quad$ Kekuatan (Strength)}

1. Bangunan Bendung berfungsi baik dan dapat dioperasikan

2. Bangunan Pintu Bendung berfungsi baik dan dapat dioperasikan

3. Bangunan Kantong Lumpur berfungsi baik dan dapat dioperasikan

4. Bangunan Pintu Penguras berfungsi baik dan dapat dioperasikan

5. Bangunan Bagi berfungsi baik dan dapat dioperasikan

6. Pembagian dan pemberian air irigasi merata dan adil

7. Pengaturan dan penyusunan $\mathrm{OP}$ bertanggung jawab

8. HIPPA sudah berbadan hukum

9. HIPPA sudah baik dan berkembang

10. HIPPA rutin melaksanakan penelusuran jaringan irigasi yang rusak

\section{- Kelemahan (Weakness)}

1. Saluran irigasi tidak mampu mengalirkan air sesuai dengan kebutuhan

2. Bangunan gorong-gorong dan talang beberapa mengalami kerusakan

3. Saluran drainase kurang berfungsi dengan baik

4. Jalan masuk ke bangunan utama kurang bagus

5. Jalan inspeksi dan jalan setapak kurang bagus

6. Kantor dan perumahan untuk mantri kurang layak

7. Rusaknya spillway pada bangunan utama

8. Realisasi tanam tidak sesuai dengan rencana tanam

9. Produktivitas padi dibawah produktivitas padi rata-rata

10. Kurangnya pengetahuan HIPPA dalam melaksanakan OP jaringan irigasi

11. HIPPA kurang aktif dalam melaksanakan rapat dengan UPTD

12. HIPPA kurang aktif dalam usulan rencanan tata tanam

- Peluang (Opportunity)

1. Tambahan bantuan dana OP dan rehabilitasi dari Pemerintah

2. Rencana tata tanam sesuai dengan karakteristik lahan dan ketersediaan air

3. Peningkatan produktivitas tanam

4. Peluang adanya teknologi budidaya baru untuk meningkatkan produktivitas tanam 
- Ancaman (Threat)

1. Tingginya sedimentasi menyebabkan fungsi jaringan irigasi kurang optimal

2. Jumlah lahan sawah mengalami penurunan

3. Harga produk mengalami fluktuasi

4. Keengganan masyarakat menjadi petani

5. Masih banyak pengambilan air yang dilakukan secara liar di daerah irigasi

6. Petani masih suka dengan cara konvensional

Setelah menganalisis faktor-faktor strategis internal dan eksternal, dilakukan penilaian bobot dan rating dari setiap faktor internal dan eksternal yang didapatkan dari hasil kuisioner SWOT. Selanjutnya, untuk merumuskan strategi yang tepat untuk meningkatkan kinerja operasi dan pemeliharaan Jaringan Irigasi Pacal penulis menggunakan 2 metode, yaitu Matriks SWOT dan Diagram SWOT.

Teknik untuk menyusun strategi-strategi yang dibutuhkan adalah dengan menggabungkan faktor kekuatan (Strength), faktor kelemahan (Weakness), faktor peluang (Oppurtunity) dan faktor ancaman (Treath) menjadi satu matriks yang diidentifikasi semua aspek dari SWOT, kemudian dari kuadran bertemunya SWOT tersebut dibuat strategistrategi yang dinamakan Matriks SWOT.

Hasil dari Matriks SWOT didapatkan 4 (empat) strategi alternatif yang dapat digunakan sebagai strategi untuk meningkatkan kinerja operasi dan pemeliharaan Jaringan Irigasi Pacal di Kabupaten Bojonegoro, yaitu :

a. Strategi S-0

- Mengoptimalkan kegiatan OP dengan bantuan dana dari Pemerintah (S 1,2,3,4,5 : P1)

- HIPPA dapat mengusulkan rencana tata tanam apabila pola tanam pada saat ini tidak sesuai dengan kebutuhan air dari masingmasing Daerah Irigasi Pacal. (S 9 : P 2)

- Mengoptimalkan fungsi dari Bangunan Irigasi dalam meningkatkan produktivitas tanam. (S 1,2,3,4,5: P 3)

- HIPPA bekerja sama dengan Dinas Pengairan maupun pihak akademis dalam pengembangan teknologi budidaya baru. ( $\mathrm{S}$ $8,9: \mathrm{P} 4)$

b. Strategi S-T

- Memberikan kesadaran kepada masyarakat yang masih banyak melakukan pengambilan air secara liar dan menerapkan sangsi yang tegas. (S 7,9,10: T 5)
- HIPPA mengadakan penyuluhan kepada masyarakat secara intensif dalam hal teknologi budidaya baru. (S 7,8,9: T 6)

- HIPPA membuat usulan kepada Pemerintah Daerah maupun instansi yang berwenang dalam hal tata ruang untuk lahan irigasi serta menekan laju konversi lahan pertanian yang akan digunakan sebagai lahan non pertanian. (S 8,9: T 2)

- Mengoptimalkan fungsi dari bangunanbangunan irigasi serta partisipasi dari HIPPA agar fungsi bangunan irigasi lebih optimal. (S $1,2,3,4,5,10: \mathrm{T} 1)$

- HIPPA mengadakan pembinaan serta ketrampilan tentang agrobisnis untuk menciptakan lapangan pekerjaan pada usaha tani. (S 8,9 : T 4)

c. Strategi W-O

- HIPPA mengajukan usulan tambahan dana OP untuk memperbaiki bangunan-bangunan irigasi yang mengalami kerusakan dan kurang berfungsi dengan baik (W $1,2,3,4,5,6,7: \mathrm{P} 1)$

- HIPPA melakukan kerja sama dengan Dinas Pengairan untuk mengadakan sosialisasi terhadap pentingnya pelaksanaan kegiatan OP dalam meningkatkan produktivitas tanam. (W8,9,10 : P1,2,3)

d. Strategi W-T

- Melakukan sangsi yang tegas dengan cara penertiban pompa liar serta penutupan sumur-sumur yang digunakan untuk pengambilan air secara liar. (W 9: T 5)

- HIPPA bekerja sama untuk gotong royong pembersihan sedimen di Jaringan-Jaringan Irigasi Pacal. (W 1,2,3,10 : T 1)

Dalam perhitungan Matriks IFAS, diketahui total nilai Kekuatan dikurangi total nilai Kelemahan sebesar 0,03. Dan hasil perhitungan Matriks EFAS, diketahui total nilai Peluang dikurangi total nilai Ancaman sebesar 0,09. Selanjutnya, diplot ke dalam Diagram SWOT untuk mendapatkan strategi yang akan dipilih. Diagram SWOT pada Gambar 7 menunjukkan letak koordinar yaitu $(0,03: 0,09)$, maka dapat diketahui posisi tersebut berada pada kuadran IB yaitu Pertumbuhan (Growth). 


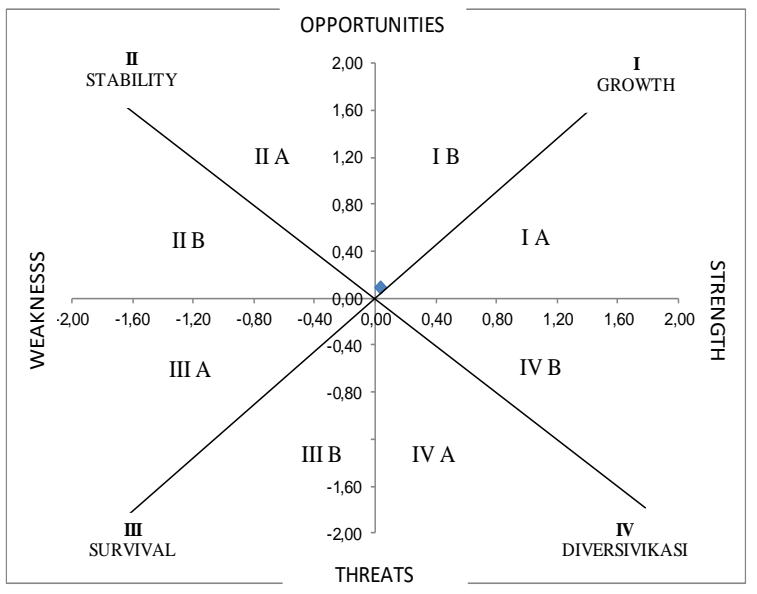

Gambar 7. Diagram SWOT

\section{KESIMPULAN DAN SARAN \\ 6.1 Kesimpulan}

Berdasarkan hasil penelitian, maka dapat ditarik kesimpulan sebagai berikut :

1. Berdasarkan analisis kondisi eksisting, untuk kondisi Jaringan Irigasi Pacal Kabupaten Bojonegoro diketahui bahwa tingkat kerusakan dari tingkat kerusakan Baik, Rusak Ringan (<10\%), Rusak Sedang (10\%-20\%), dan Rusak Berat (>40\%) terjadi pada beberapa bangunan irigasi. Hal ini perlu segera dilakukan perbaikan untuk meningkatkan kinerja operasi dan pemeliharaan Jaringan Irigasi Pacal.

Untuk realisasi tanam serta intensitas tanam Daerah Irigasi Pacal masih dapat ditingkatkan jika kinerja operasi dan pemeliharaannya dapat meningkat.

Dari sisi pemenuhan kebutuhan air irigasi, sistem pemberian air irigasi Daerah Irigasi Pacal dilakukan dengan sistem gilir maupun golongan untuk mencukupi kebutuhan air tanaman.

2. Berdasarkan analisis kuadran, yang menjadi faktor prioritas utama dalam peningkatan kinerja OP Jaringan Irigasi Pacal menurut para pertani HIPPA bagian hulu, tengah, hilir adalah :

- Perbaikan saluran irigasi (sub variabel $\mathrm{X} 1.5$ )

- Perbaikan bangunan gorong-gorong dan talang (sub variabel X1.7)

- Perbaikan saluran drainase (sub variabel $\mathrm{X} 1.8$ )

- Perbaikan jalan masuk ke bangunan utama (sub variabel X1.9)
- Perbaikan jalan isnpeksi dan jalan setapak di sepanjang saluran (sub variabel X1.10)

- Perbaikan kantor dan perumahan untuk mantri (sub variabel X1.11)

- Realisasi Tanam (sub variabel X2.2)

- Produktivitas padi (sub variabel X2.3)

- Pengetahuan Anggota HIPPA(sub variabel $\mathrm{X} 4.3$ )

- Keaktifan HIPPA dalam rapat dengan UPTD (sub variabel X6.3)

- Keaktifan HIPPA dalam usulan rencana tata tanam (sub variabel X6.6)

3. Berdasarkan analisis SWOT IFAS EFAS, posisi strategi yang disarankan untuk peningkatan kinerja OP Jaringan Irigasi Pacal adalah strategi Growth, yaitu strategi memaksimalkan kekuatan yang dimiliki untuk memanfaatkan peluang yang ada. Adapun strategi tersebut adalah :

- Mengoptimalkan kegiatan OP dengan bantuan dana dari Pemerintah (S 1,2,3,4,5 : P1)

- HIPPA dapat mengusulkan rencana tata tanam apabila pola tanam pada saat ini tidak sesuai dengan kebutuhan air dari masing-masing Daerah Irigasi Pacal. (S 9 : P 2)

- Mengoptimalkan fungsi dari Bangunan Irigasi dalam meningkatkan produktivitas tanam. (S 1,2,3,4,5 : P 3)

- HIPPA bekerja sama dengan Dinas Pengairan maupun pihak akademis dalam pengembangan teknologi budidaya baru. (S 8,9 : P 4)

\subsection{Saran}

Adapun saran untuk penelitian ini adalah :

1. Bagi Pengelola Irigasi

Dalam penelitian ini diharapkan pengelola irigasi yang terkait dapat melakukan pengawasan serta evaluasi yang berkesinambungan untuk meningkatkan kinerja OP Jaringan Irigasi Pacal dengan memperhatikan atribut-atribut yang menjadi prioritas utama.

2. Bagi Pemerintah

Pemerintah dapat bekerja sama dengan anggota HIPPA dalam meningkatkan kinerja OP Jaringan Irigasi Pacal. Salah satunya dengan memberikan kontribusi berupa bantuan dana untuk perbaikan bangunan-bangunan irigasi yang mengalami kerusakan sehingga kinerja OP lebih optimal. 
3. Bagi Peneliti

Bagi penelitian selanjutnya, dalam mengimplementasikan strategi peningkatan kinerja operasi dan pemeliharaan Jaringan Irigasi Pacal yang sudah dirumuskan, diperlukan penelitian lebih lanjut tentang efektifitas strategi tersebut.

\section{DAFTAR PUSTAKA}

[1] Departemen Pekerjaan Umum. (2007). Peraturan Menteri Pekerjaan Umum Nomor 32/PRT/M/2007 tentang Operasi dan Pemeliharaan Jaringan Irigasi, Lampiran I Indeks Kinerja Sistem Irigasi.

[2] Kartasapoetra, A. G., dan Mul Mulyani Sutedjo., 1994. Tekhnologi Pengairan. http://www.pdf.com (diakses pada 22 Oktober 2016).

[3] Peraturan Pemerintah Tentang Irigasi, (2006). Peraturan Pemerintah Republik Indonesia. http://www.pdf.com (diakses pada 12 Oktober 2016).

[4] Rangkuti, F. (2005). Analisis SWOT Teknik Membedah Kasus Bisnis, PT. Gramedia Pustaka Utama, Jakarta.

[5] Sugiono. (2005). Statistik Untuk Penelitian, Alfabeta, Bandung.

[6] Sugiyono.(2010). Metode Penelitian Kuantitatif Kualitatif \& RND. Alfabeta, Bandung.

[7] Sumaryanto, dkk., (2006). Evaluasi Kinerja Operasi dan Pemeliharaan Jaringan Irigasi dan Upaya Perbaikannya. http://www.pdf.com (diakses pada 20 Oktober 2016). 